\title{
The Status of Employees and Their Involvement in the Decision-Making Process of a Commercial Company
}

\author{
Prof. As. Dr. Eneida Sema (Dervishi) \\ Professor at the Civil Rights Department, Faculty of Law, University of Tirana \\ Email: eneidasema@yahoo.com
}

Pierind Çukaj

Email: pierindcukaj@gmail.com

Doi:10.5901/ajis.2016.v5n3s1p471

\begin{abstract}
Labor Law is the branch of law which constitutes a significant part of the legal order in a given society. The importance of this legal order is in the fact that labor relations as legal relations directly affect and relates to the progress of economic and social development of the society, as work is a source of income for the subjects of law. The existence of representative bodies of simple employees in the decision-making process, in an organized manner, is an important aspect, but it also entails some problems. Partnership between the company and employees is a legal, social, economic and political connection, which has considerable impact on society. Protecting the rights of employees in a corporation is better achieved if its management structure would include representatives bodies of workers. Involvement of employees in the management and administration of the company is already an international standard. Globalization of the economy and the crucial role that a business has in a country or wider, makes the involvement of employees necessary.
\end{abstract}

Keywords: employee, decision-making, trade associations

\section{The History and Development of Labor Law}

The right to work was born for the first time in the second half of 800 's, having as its source plant legislation, that part of the capitalist civil laws regulating the labor subscription contract, the practice of collective bargaining and those administrative law norms regulating legal relations of civil workers of the state apparatus. ${ }^{1}$ Labour Law is one of the newest branches of law which is constantly evolving. It was first presented in capitalist countries by the end of the XIX century. At first it appears in Germany as a result of the birth and development of paid work, whose economy is based on freedom of market and industry. The right to work is a separate discipline and positive legal branch, which has the object of special regulation and study, its purpose, its principles, special legal meanings, institutions, and its categories. ${ }^{2}$ In its beginning, right to work was like any other branch of law since it had failed to separate and it functioned together with other norms of other branches of law. Division of labor law from civil and administrative law happened in later stages of state-building processes in different countries. This division occurred in the period of largest industry development and industrial enterprises. Hired labor in early 19th-century, was subject to the rules of contract principles of reconciliation and service, regulated by the Civil Code of the capitalist countries. Labor relations are mainly treated as contractual relationship regulated by contractual law. Typical in this respect was the Napoleonic Civil Code of the year 1804 and the Italian Civil Code of 1865, the Austrian Civil Code of 1811, which predicted and also regulate the labor agreement. ${ }^{3}$ With the development of the capitalist countries and the growth and development of labor relations it is necessary to regulate the employment of specific provisions and separate from other branches of law which started in England 1802.1811, 1833, etc., in Germany 1839 and in France $1841 .{ }^{4}$ From the late nineteenth century and early twentieth century labor

\footnotetext{
1 Prof.Dr.Kudret Çela, "Labour Law”, IV Publication, Tiranë 2003, pg.18.

2 Prof. Dr. Fatmire Lumani “Labour Law”, Tetovë 2013, pg.7.

3 Prof. Dr. Fatmire Lumani “Labour Law”, Tetovë 2013, pg.8.

4 Prof. Dr. Fatmire Lumani “Labour Law”, Tetovë 2013, pg.9. 
unions were created, and their reaction and pressure created collective labor contracts, which led to the development of the labor legislation. During this period, capitalist states interfered with legislative initiatives with new legal norms to regulate legal labor relations. In some states provisions that regulate the employment relationship stowed in special codes as in France (Labour Code, 1910, 1912, 1924, 1927), in Austria (1928, Belgium (1900, 1922), the Netherlands $(1919,1930)$, in Italy (1927, in Germany (1934), the US (1935). ${ }^{5}$

\section{The Meaning of Labor Law}

The right to work has a special significance in social relationships. ${ }^{6}$ It is a set of rules that apply to dependent employment relationship. ${ }^{7}$ This working relationship is constituted on a contract concluded between the parties and called a labor contract. ${ }^{8}$ The right to work is as modern as it is old. This is a separate branch of law because it has a special object ${ }^{9}$ and subjects and has a special quality. ${ }^{10}$ Social relationship that serves to establish the working relationship has special qualities because it is not like any other social relationship that serves to establish a civil legal relationship. The right to work has its own internal divisions, according to the areas that labor law regulates. In itself the right to work is a branch of law that regulates the relationship between employers and employees working in a dependent relationship. The fact that labor law has a special object of regulation and enables study of its existence as an independent branch of law. Marinko Uçuk gave this definition of the right to work: "The right to work is a separate branch of the positive legal state composition. It includes general legal rules that govern labor relations, concepts, categories and institutes of labor law of those legal relations established or legally accepted and regulates, implements directly the legal labor relations, protects the rights and its subjects. In addition it contains legal norms on the principles, organization of work, safety at work, as well as institutions in connection with work and relationships at work ".11 Labor Law of the Republic of Albania is a set of legal norms in terms of our democratic society regulating dependent labor relations. ${ }^{12}$

\section{Labor Relations in the Legal Entity}

Labor relations in the legal person may have several dimensions. These relationships are very important because they represent some specifics in the legal perspective. From the legal person, working relationships may arise, that are configured by an employment contract and thus subject to the Labour Code to resolve any conflict that may arise between the parties. But there could exist working positions in which individuals who establish a working relationship with a legal entity are placed but that are not subject to the Labour Code. Legal persons can be of various kinds. There are two major divisions. Legal persons that are public entities and private entities. In the scope of our paper, our issue of labor relations revolves in the second category of legal persons, including trade associations and nonprofit organizations. Before analyzing some specific work position we should explain some concepts of the legal person and see how it works.

\section{Participation of Simple Employees in Companies}

These legal entities are commercial companies that have some important qualities. Generally they are called commercial companies in a new form of joint stock companies, but in the Anglo-American countries. In the old continent of Europe, such companies are simply called as a joint stock, limited liability company, etc. Five main structural features of corporate business are: being a legal entity, has limited liability, capital is divided into transferable shares, usually has a centralized management in a structure of the board and ownership is shared by contributors of capital. The Corporation has the property itself. Involvement of employees in the management and administration of the company is already a European

\footnotetext{
5 Prof. Dr. Fatmire Lumani “Labour Law”, Tetovë 2013, pg.19.

${ }^{6}$ Prof. Dr. Kudret Çela, "Labour Law ",Tiranë 2010, pg. 19.

7 Gerard Cornu, " Vocabulaire Juridique", Paris, 1987, pg. 290.

${ }^{8}$ Law nr. 7961, date 12.7.1995, "On the Labour Code of the Republic of Albania", amended, Art. 12:" In the employment contract, the employee undertakes to provide work or its service for a certain period or indefinite within the organization and under the orders of another person, called the employer who undertakes to pay a ransom. "

9 Prof. Dr. Kudret Çela, "Labour Law", XII Publication, Tiranë 2010, pg. 24.

10 Prof. Dr. Kudret Çela, "Labour Law ", XII Publication, Tiranë 2010, pg.20.

11 Prof. Dr. Fatmire Lumani “Labour Law", Tetovë 2013, pg.10

12 Prof. Dr. Kudret Çela, "Labour Law”, IV Publication, Tiranë 2003, pg.15.
} 
standard. Albania has already consolidated trading law with the European standards to better enable employee participation in the affairs of ordinary companies. European Union itself has given special importance to the involvement of employees. Globalization of the economy and the special place that a business has in a country or wider, made involvement of employees needed. The partnership between the company and employees is a social, economic and political relation, which has more impact on society. It is unjust that the relationship between the company and its employees to be a one-sided relationship, where only one party benefits against another party. This relationship is understood in a way that the company is in a position of superiority and therein is required by law to regulate and guarantee the rights of its workers. It is important to study the participation of other ordinary employees in their relationship with the company, not only the analysis that deals with subjects that have special places of work in a company. A business decisions has always constituted its impact on employees. Workers should be involved in decision making at all levels of a company. ${ }^{13}$ Albanian law for traders and trading companies foresees the participation of workers. ${ }^{14}$ The model is taken by the European legislation. The latest issue has the effect of Directive 94/45 / EC, "For European works councils," which stipulates the creation of works councils in all business organization stretching across Europe. Also in this context it is Directive 2002/14 / EC "On information and consultation of employees." Regulation 2157/2001 "European Society", provides for the participation of employees with their own councils. As evidenced above, our law is in line with the developments of European legislation. Employee Council monitors the implementation of laws, collective agreements and the provisions of the statute and represents the interests of company employees. The Council participates in decision-making on the use of special funds and other assets of the company, provided for in the collective agreements and statutes, as well as on the distribution of profits that the General Assembly decides to distribute to the employees..$^{15}$ The council may establish internal regulations to organize its procedures. ${ }^{16}$ The legal representative of the company holds council employees informed about the activities and the performance of the company in order to separate the effects of the company's policies on working conditions, wages, safety, possible division of profits, change of status, pension system, company restructuring and company's participation in other companies.

The Legal representative, at the request of the Employee Council, presents the state of the accounts, including consolidated accounts, reports on the state of progress of the activities of the company, the Supervisory Board reports or the expert accountant reports. This obligation can be fulfilled by placing this information on the website of the company and informing employees of this council. In contrast, the responses may be required to be in writing, using electronic means of communication. ${ }^{17}$ The above provizions of our law for traders and trading companies is fully in line with the above regulations and the European Union Directive 2001/86 / EC. The Charter may provide that one or several members of the council of surveillance get appointed and discharged by the employee. ${ }^{18}$ All employees in the company, enter into a working relationship and formalize this relationship by an employment contract and governed by the Labor Code. Any dispute between employees and the company is resolved on the basis of the Labour Code. When commercial law provides for the participation of employees in the assembly and the council of employees, it does not create a new working relationship. It can not be called a working relationship. These bodies do not intend to employ employees who are actually employed. Provisions of the law aim to guarantee the right of workers who are already employed in the company, the ability to organize themselves in order to be a unified voice, thus becoming an important voice in the decision-making process and the policies of the company. They are selected in these bodies and do not enter into a contract when appointed. In fact, being employed by the company is a premise that they can be included in these important structures to defend their rights. These are formal structures and the company should ensure the logistics and financial opportunities needed. Also these are formal structures by which cells initiate trade union movements to the creation of unions of employees. This is a constitutional right of workers in an employment relationship. It provides that employees have the right to unite freely in labor organizations for the protection of their labor interests. ${ }^{19}$ Employees have the right to a social protection of labor. ${ }^{20}$ As such it must be guaranteed and taken measures to make its realization possible. It is possible that the legal possibility of creating and participating in these structures is to enable them to

\footnotetext{
${ }^{13}$ Report "Davignon", European Commission, May 1997, prgf. 19.

14 Law Nr.9901 date 14.4.2008 "For tradres and trading companies", Art. 19.

15 Law Nr.9901 date 14.4.2008 "For tradres and trading companies", Art. 20.

16 Law Nr.9901 date 14.4.2008 "For tradres and trading companies", Art. 19.

17 Law Nr.9901 date 14.4.2008 "For traders and trading companies", Art. 21.

18 Law Nr.9901 date 14.4.2008 "For traders and trading companies", Art. 167/4/2.

${ }^{19}$ Constitution of the Albanian Republic, approved by law nr.8417, date 21.10.1998 amended, Art. 50.

20 Constitution of the Albanian Republic, approved by law nr.8417, date 21.10.1998 amended, Art. 49.
} 
exercise their constitutional rights and freedoms. When they are against the decisions of the decision-making organs of the company, it is possible to reject through petitions, strikes and other democratic means. ${ }^{21}$ There can be no parallelism in particular positions of some entities working in a company, offering their services and being rewarded for the job. So these are the bodies that are provided by trade law, but these are formal bodies and of a political character. People who participate in these bodies are also in the same time employees of the company. They are representative dues, as representing all the other employees of the company. These people do not sign a contract, they are just appointed formally in order to preserve the rights of other employees and to make their voice heard in front the organs of the company who can make the decision relevant to their lives in terms of labor relations and investment policy, trading, expansion of activity or in the worst case, the closure of the company due to its bankruptcy. In fact, Albania has these structures provided by law following the best models of the developed capitalist world, where participation of employees in decision making through these structures is necessary to ensure the protection of the rights of employees who are employed in these companies. The European Union and its legislation is one of the models followed.

\section{Participation of Employees in Companies in the EU}

This issue is not new to the EU legislation. But we can say that until the adopted EU Directive 2002/14 of 11 March there was no act that dealt with that issue. ${ }^{22}$ Regulating the issue was due to trade union movements. Before listing the participation of employees in the company under European Union legislation we must clarify the concept of a company in the community. This is a very important notion to be clarified. On the basis of this notion, any work relationship, administration, supervision or control is created. Labor relations on this notion gave rise to some specific working positions. This notion is associated with competition rules. ${ }^{23}$ Although it has a very special significant notion of a company, European legislation itself does not provide a definition of what does a trading company mean. The first attempt to give a definition of this notion, is the European Court of Justice. In fact, this body returned in the key of resolving the legal deadlock or legal vacuums. Pursuant to this court's decision, business is any entity exercising economic activity, regardless of its legal form and method of organization. ${ }^{24}$ Economic activity is any activity consisting in offering goods or services in a given market. ${ }^{25}$ This is the key feature to distinguish the entity in the sense of a company. At first it was not intended for any organ of the representative of the employees to be created in a company. What was usually needed was to enlarge national corporations or international culture. Defending the rights of workers in a corporation would be better if a worker's representative body is part of the company's structure. This makes them more organized and their requirements are more concrete. Directive 1994/45 of 22 September not only anticipated corporate obligation to inform and consult with employees about policies that the company will take, but also provided the obligation to create representative bodies for employees. The principle on which to act, was the principle of defense of workers, the principle of cooperation, the principle of autonomy of the respective parties, the principle of good faith, the principle of subsidiarity, and the principle of confidentiality and consensuality. ${ }^{26}$ The Directive provided for the number of representatives in these bodies, depending on the total number of employees in a company.

Later on, Directive 2009/38 of 6 May is another positive step towards engaging employees in decision-making and corporate issues related to the interests of employees. It is possible for the parties to enter into negotiations to resolve various issues. This may create committees with the consent of the parties, which were composed of representatives from both parties. ${ }^{27}$ Corporations need to develop consultation under the principle of autonomy before deciding on the matter. The obligation to do so before the decision was in the case of information to employees. After several years, the drafting and adoption of a regulation on collective representation of employees was adopted. It was Reg. 2157/2001. The unification regarding the participation of workers in the decision-making process was higher with the adoption of this

\footnotetext{
${ }^{21}$ Constitution of the Albanian Republic, approved by law nr.8417, date 21.10.1998 amended, Art. 51.

22 Sylvie Hennion, Muriel Le Barbier-Le Bris, Marion Del Sol, " International and European Social Right ", Pub. "PAPIRUS", Tiranë 2010, pg. 355.

23 TFEU, Art. 101/1.

${ }^{24}$ ECJ, Case c-41/ 90 e 23 April 1991, "Hofner et Elser".

${ }^{25}$ ECJ, Case c-180/ 98 e 12 December 2000, "Pavel Pavlov".

26 Sylvie Hennion, Muriel Le Barbier-Le Bris, Marion Del Sol, " International and European Social Right ", Pub. "PAPIRUS", Tiranë 2010, pg. 361-362.

${ }_{27}$ Sylvie Hennion, Muriel Le Barbier-Le Bris, Marion Del Sol, " International and European Social Right ", Pub. "PAPIRUS", Tiranë 2010, pg. 367.
} 
Regulation. Many issues not foreseen were already so different from one national legislation of member states to the other. On the legal basis in the European Union, the participation of employees in companies is provided the same under Albanian trade law. Differently from the Administrator of a company which signs a specific contract, no contract is signed by the representatives. The European Union has had a growing amplitude regarding his attention to labor rights, the status of the employee, the employment contract and the rights of employees in labor relations.

\section{Sources of Labor Law Regulating the Status of the Employee}

EU resources are divided into two categories. The main sources include the founding treaty of the European Union itself and in secondary sources there are all acts adopted in accordance to the main sources. General principles relating to the mechanisms of control by Member States of the Council regarding implementing powers are also one of the important primary sources. ${ }^{28}$ In order to know the general principles of law applicable in Community law, reference should be made to the Court of Justice jurisprudence and the doctrine of recognized rules of law of the member states. ${ }^{29}$ The Court of Justice of the European Union has an excellent contribution to its decisions. Its decisions constitute in a source of law and must be implemented. For example, a principle that the court has established, among the many ${ }^{30}$, is the responsibility of member states for individuals who experience damage as a result of violations of EU law. ${ }^{31} \mathrm{EU}$ concludes agreements with non-member states and other international organizations and these are the most varied, making these agreements part of its own resources.

Secondary right of the European Union involves a large number of important acts, most of which are cited in Article 243 of the Treaty on the Functioning of the European Union. Article 243 states: "... institutions governing regulations and directives, make decisions and formulate recommendations or opinions." The regulations are very important acts. A regulation shall have general application, it must be related to the people as a whole self and be directly applicable in all member states..$^{32}$ In addition to regulation, the more important acts are the EU Directives. The Directive is connected with the result that will be achieved on each member state to which it applies, and internal institutions choose the form and method to achieve this result. Directive differ from the regulations in several ways. ${ }^{33}$ They do not have general application and thus are not even addressed to all member states. They are not directly applicable and the effects of the rights and obligations created of them are felt only when they are brought into law by public institutions. This autonomy allows more flexibility in their implementation. In the category of acts, decisions are also important. ${ }^{34}$ Decisions are similar to Regulations because there is no direct application and implementation. Recommendations and opinions are not binding. ${ }^{35}$ They have no binding force although it should be taken into consideration by the domestic courts. The affirmation of the supremacy of Community law over national rights, ${ }^{36}$ enforcement of the community norms that are directly related to the subjects whose final addresses ${ }^{37}$ and referral regarding basic human rights can be considered as the real legal community regime. ${ }^{38}$ Some key acts of the European Union on the right to work and the regulation of their working relation and the status of the employee in this relationship can be: Treaty on the Functioning of the European Union (Articles 44-45 and 145-164), the Convention of the European Union Fundamental Rights, Directive no. 79/7 / EEC of 19 December 1978 "On the progressive implementation of the principle of equal treatment for men and women in matters of social security", the Directive no. 86/378 / EEC, 24 July 1986 "On the implementation of the principle of equal treatment in occupational social security schemes", Reg. 1408/71 of the Council of 14 June 1971 "On application of a social security schemes to employed persons and their families moving within the community", Reg. 859/2003, May 14, 2003 "On the extension of the provisions of Regulation 1408/71 and Regulation (EEC) 574/72 to nationals of third countries who are not covered by these schemes based solely on citizenship", Reg. 883/2004 of the European

28 TFEU, Art. 291.

${ }^{29}$ ECJ, Case "Algera ", 12.07.1957.

${ }^{30}$ ECJ Cases 5 March 1996. C- 46/93" Brasserie du du pêçeur" and C-48/93 "Factortame".

${ }^{31}$ ECJ Cases 5 March 1996. C- 46/93" Brasserie du du pêçeur" and C-48/93 "Factortame".

32 TFEU, Art. 288.

33 TFEU, Art. 249.

34 TFEU, Art. 249.

${ }_{35}$ ECJ, Case Costa v ENEL 15 July 1964.

${ }^{36}$ ECJ, Case Simmenthal 9 mars 1978.

${ }^{37}$ ECJ, Case Van Gend \& Loos5 shkurt 1963.

${ }^{38}$ ECJ, Case Handelsgesellschaft, 17 December 1970. 
Parliament and the Council, April 29, 2004 "On the coordination of social security systems". 39 Council Directive. 75/117 I EEC of 10 February 1975 "On the approximation of the laws of the Member States relating to the principle of equal pay for men and women and men and women teachers with full-time and part-time", Council Directive nr. 92/85 / EEC "On maternity leave - benefit from the rising profits based on women - Increase in salary before or during maternity leave. ${ }^{40 "}$ May also be mentioned, Regulation no. Council 1612/68 dated 15 October 1968, "Regarding the free movement of workers in the Community", Council Directive 80/987 / EC of 20 October $1980^{41}$, "Regarding the protection of employees in the event of bankruptcy of the employer, which sought to protect the rights of employees to be paid in the period preceding insolvency and dismissal due to bankruptcy ${ }^{42}$, "Directive 76/207 / EEC states that national law should plan effective penalties to ensure the provision of equal opportunities regarding access to employment, Directive 1999/70 / EC of 28 June 1999, "For the work of a specified duration", Directive 1997/81 / EC of 15 December 1997, "On part-time work "; Reg. 593/2008 of 17 June 2008, "On the law applicable to contractual obligations", called "Rome I", which mainly regulates international labor contract, Regulation no. 44/2001 of 22 December 2000, "On the court's competence to deal with the recognition and enforcement of judgments in civil and commercial field ", but also many other acts of this kind. This list can not be exhaustive, but this is only to bring in the attention the European Union labor law.

\section{Conclusions and Recommendations}

Analysis on several dimensions of employment and the contract governing this relationship were made. on the one hand, the position of persons who have a special place of work in commercial companies in a comparative view including also the status of employees under the legislation of the European Union and the practice of the European Court of Justice were discussed. On these conclusion are set out some recommendations in function of solving the problems that the law and practice. In a company that usually has a very large extent, the participation of simple employees in this company is important. Generally these companies are called large corporations. Simple employee conclude a contract with the company. But as our drafted commercial legislation was guided by models and better standards of the EU legislation foresees the possibility of participation of employees in commercial society. They can be organized in representative bodies, which are part of the company's structure. It should be said that the appointment of the employees in these bodies did not hire them for the second time. They do not enter into a contract when appointed. In fact being employed by the company is a premise that they could be included in these important structures to defend their rights. These formal and structured companies should ensure the logistics and financial opportunities that arise. This is a constitutional right of the employee in a working relationship. It provides that employees have the right to unite freely in labor organizations for the protection of their labor interests. Employees have the right to social protection of labor. As such must be guaranteed and take measures to make it possible as its realization. The above provisions of our law for traders and companies is fully in line with the above regulations and the European Union Directive 2001/86 / EC. Workers who should be involved in decision making at all levels of society. Our law for traders and trading company foresees the participation of workers. The latest issue has the effect of Directive 94/45 / EC, "For European works councils," which stipulates the creation of works councils in all business organization stretching across Europe. Also in this context it is Directive 2002/14 / EC "On information and consultation of employees." Regulation 2157/2001 "European Society", provides for the participation of employees.

As evidenced above our law is in line with the developments of the European legislation. Employee Council monitors the implementation of laws, collective agreements and the provisions of the statute and represents the interests of company employees. The council may establish internal regulations to organize its procedures. The legal representative of the company has the duty to hold council employees informed about the activities and on the performance of the company in order to separate the effects of the company's policies on working conditions, wages, safety, possible division of profits, change of status, pension system, company restructuring and society participation in other companies. People who participate in these bodies are also in the same time employees of the company. They are representative dues, as representing all the other employees of the company. These people do not sign a contract, they

${ }^{39}$ European Commission. General Employment Office, social and inclusive issues.

http://europa.eu/legislation_summaries/employment_and_social_policy/index_en.htm.

40 ECJ, Case C-285/02, GJED, Luksemburg, 27 May 2004.

41 ECJ, Case "Marleasing", 13 November 1990,

42 Francovich and Bonifaci, in 1991, ECJ considers member states responsible for paying damages when caused as a result of failure of full or partial implementation of the Directive. 
just get appointed formally in order to preserve the rights of employees relevant to their lives in terms of labor relations and investment policy, trading, expansion of activity or in the worst case the closure of the company due to its bankruptcy. On the status of employees in the comparison field we can say that this is an area that still requires study and do more research. This paper has focused on some concrete aspects that have also practical value since the status of employees is very important to be understood in all its dimension.

\section{References}

Treaty of Functionig of the European Union.

Law Nr.9901 date 14.4.2008 "For traders and trading companies".

Constitution of the Albanian Republic, approved by law nr.8417, date 21.10.1998 amended.

Law nr. 7961, date 12.7.1995, "On the Labour Code of the Republic of Albania", amended.

Report "Davignon", European Commission, May 1997.

Prof. Dr. Kudret Çela, " Labour Law ", XII Publication, Tiranë 2010.

Sylvie Hennion, Muriel Le Barbier-Le Bris, Marion Del Sol, " International and European Social Right ", Pub."PAPIRUS", Tiranë 2010.

Prof. Dr. Fatmire Lumani "Labour Law", Tetovë 2013.

Gerard Cornu, " Vocabulaire Juridique", Paris, 1987.

Prof. Dr. Kudret Çela, "Labour Law", IV Publication, Tiranë 2003.

ECJ, Case Costa v ENEL 15 July 1964.

ECJ, Case Simmenthal 9 mars 1978.

ECJ, Case Van Gend \& Loos5 shkurt 1963.

ECJ, Case Handelsgesellschaft, 17 December 1970.

ECJ, Case C-285/02, GJED, Luksemburg, 27 May 2004.

ECJ, Case "Marleasing", 13 November 1990

ECJ, Case "Algera ", 12.07.1957.

ECJ Cases 5 March 1996. C- 46/93" Brasserie du du pêçeur" and C-48/93 "Factortame".

ECJ, Case c-41/ 90 e 23 April 1991, "Hofner et Elser".

ECJ, Case c-180/ 98 e 12 December 2000, "Pavel Pavlov".

European Commission. General Employment Office, social and inclusive issues.

http://europa.eu/legislation_summaries/employment_and_social_policy/index_en.htm 